\title{
СЕМАНТИК-СИНТАКТИК АНАЛИЗАТОРЛАР ХУСУСИДА
}

\section{Гулямова Шахноза Кахрамоновна}

bunnycham@mail.ru

Алишер Навоий номидаги Тошкент давлат ўзбек тили ва адабиёти университети докторанти Филология фанлари бўйича фалсафа доктори $(\mathrm{PhD})$

Аннотация. Ушбу мақолада семантик-синтактик анализаторларнинг мақсад ва вазифаси ёритилган. PROMT Syntactic and Semantic Analyzer, TextAnalyst ${ }^{\mathrm{TM}}$, семантик-синтактик (SemSin) парсернинг ахамияти борасида фикр юритилган. Ўзбек тили семантик анализаторининг лингвистик асосларини яратиш кечиктириб бўлмас вазифа эканлиги асосланган.

Аннотация. В данной статье рассматриваются цели и задачи синтаксико-семантических анализаторов. Говорится о важности PROMT Syntactic and Semantic Analyzer, TextAnalyst ${ }^{\mathrm{TM}}$, (SemSin) семантикосинтаксического парсера. Обосновано актуальность задачи создания лингвистических основ семантического анализатора узбекского языка.

Annotation. This article discusses the goals and objectives of syntaxsemantic analyzers. It talks about the importance of PROMT Syntactic and Semantic Analyzer, TextAnalyst, (SemSin) semantic-syntactic parser. The relevance of the task of creating the linguistic foundations of the semantic analyzer of the Uzbek language is justified.

Калит сўзлар: компьютер лингвистикаси, семантик, морфологик, синтактик анализатор, PROMT Syntactic and Semantic Analyzer, TextAnalyst ${ }^{\mathrm{TM}}$, семантик құициув, семантик-синтактик (SemSin) nарсер, семантик фильтр

Лингвистик анализатор - автоматлашган қидирув тизимида табиий тилни қайта ишлаш жараёнида сўзнинг морфологик, синтактик ва семантик хусусиятини ифодалайдиган восита.

Компьютер тилшунослигида семантик анализатор тузиш махсус тадқиқ этилмаган, аммо у синтактик анализатор билан бирга ўрганилган, яратилган ва мукаммаллаштирилмокда. Д.Ш.Сулейманов, А.Р.Гатиатуллинлар татар 
морфемаларининг таркибий-функционал компьютер модели (“Структурнофункциональная компьютерная модель татарских морфем”)нинг назарий хамда амалий масалалари ечимида татар тилининг семантик-синтактик анализатори (CCA) хусусида тўхталиб ўтади. Унда ССА - татар тилининг синтактик ва семантик сатхлари прагматик йўналтирилган лингвистик моделининг концептуал-алгоритмик амалий тадбиғи эканлиги таъкидланган.

Татар иборасининг семантик ва синтактик анализатори курилишининг долзарблиги, биринчи навбатда, икки холатларда аниқланади. Бир томондан, семантик ва синтактик анализатор татар тилининг концептуал ва функционал моделини тасвирлашнинг асосий илмий-амалий вазифасининг бир қисми бўлса, бошқа томондан, татар тилидаги сўз шаклларининг чегарасида сегментацияни тўғри жойлаштиришни аниқлаш, татар нутқ синтезатори, татар-турк, татар-рус таржимонлари каби дастурий тизимларнинг сегментациясида сўзларнинг тўғри тартибини текшириш имконини берувчи амалий восита. У Татаристон Фанлар Академияси ва Қозон Давлат университетининг “Сунъий интеллект муаммолари” илмий-тадқиқот лабораториясида ишлаб чиқилди.

Хозирги кунда бу мавзу Хинд-Европа ва бошқа тил гурухида ўрганиш учун бой тарихга эга бўлиб [Ю.Д.Апресян, 1992, Н.В.Григорьев, 1999; Н.Хомский, 1962; Л.Г.Митюшин, 1996; Э.В.Страхович, 1996; И.А.Волкова, 1997], татар тили синтактик структурасининг компьютер моделини куриш доирасида дастлабки босқичда турибди.

Тилнинг компьютер семантик ва синтактик модели остида муаллифлар компьютерда амалга оширилган ва унда йўл куйилган меъёрлар нуқтаи назаридан тўғри бўлган хар хил синтактик формулаларни акс эттирувчи тил синтаксисининг концептуал ва структур моделини тушунади.

Семантик ва синтактик анализатор концептуал ва таркибий модел асосида амалга оширилиб, функционал компьютер тизими сифатида белгиланиши мумкин. Прагматик фойдаланиш орқали энг катта самарадорлик - лингвистик моделларни ишлаб чиқишга йўналтирилган технологияларга эришишдир. Синтаксис бўйича асосий материал сифатида М.З.Закиевнинг асарларидан, семантика йўналишида татар тили аффиксал морфемалари маъноларининг расмий тавсифи тизимидан фойдаланилган.

Адабиётларда семантик ва синтактик анализаторнинг структур схемаси куйидагича кўрсатилади [Сулаймонов, 2003:152]:

1. Сўз шаклларининг морфологик анализатори. 
2. Аналитик бўлинмас конструкцияларнинг детерминанти (аниқловчиси).

3. Тобелик дарахтини куриш (бу компонент гаплар орасидаги барча мумкин бўлган мувофиқликларни ўрнатадиган модуллар тўплами).

Кўринадики, семантик анализатор туркий тилларда хам алохида ишлаб чиқилмаган. Бу семантик анализатор масаласи мураккаблигини, бевосита бошқа анализаторлар билан боғлиқликда операция бажаришини кўрсатади.

Машина таржимаси сохасидаги ишланмалари билан танилган PROMT компанияси эса табиий тилда берилган матннинг морфологик, синтактик ва семантик тахлилини амалга оширувчи PROMT Syntactic and Semantic Analyzer синтактик-семантик анализаторини ишлаб чикди. Ушбу илованинг лингвистик маълумотлар базаси янги семантик синфлар ёки фойдаланувчи томонидан аниқланган синтактик моделлар сифатида 30 миллиондан ортиқ сўз шаклларини ўз ичига олади, янги сўзлар ва моделларни киритиш имконини беради. Натижа XML форматида чиқади, уни осонгина тахлил қилиш мумкин. Махсулот пакетида эксперт бахолаши учун тахлил натижаларини визуаллаштириш воситаси хам мавжуд.

Матнлар мазмунини тахлил қилиш, ахборотни семантик қидириш, электрон архивларни шакллантириш воситаси сифатида яратилган TextAnalyst ${ }^{\mathrm{TM}}$ эса фойдаланувчига куйидаги асосий хусусиятларни тақдим этади:

1) семантик тармоқда матн мазмунини хаволалари билан автоматик шакллантириш воситасида асосий тушунчалар ва маъновий боғланишлар орқали матн тасвирини қабул қилиш;

2) матннинг семантик структурасини мавзу ва субтопикларнинг иерархияси шаклида аниқлаш;

3) сўров сўзларининг матнли сўзлар билан яширин семантик боғланишларини хисобга олган холда семантик қидириш;

4) матнни автоматик хавола қилиш орқали унинг семантик портретини информацион ибораларда шакллантириш;

5) ахборотни кластерлаш - матн материалининг тематик синфлар бўйича тақсимланишини тахлил қилиш;

6) гиперматнга айлантириш билан автоматик матнли индексация;

7) матн семантикаси хақидаги барча турдаги маълумотларни “мухимлик даражаси"га кўра саралаш орқали тартиблаш;

8) гиперматнли структурага эга бўлган тўлиқ матнли билимлар базасини 
автоматик шакллантириш, маълумотларга ассоциатив кириш имкониятлари.

Юқорида таъкидланганидек, рус, европа ва айрим туркий тилларда морфологик ва семантик анализаторлар ишлаб чиқилган бўлиб, улардан самарали фойдаланилмоқда. Аммо семантик анализатор деярли яратилмаган. Корпус лингвистикасининг пешқадам олими В.П.Захаров соф холдаги семантик анализаторни икки йўл билан тушуниш мумкинлигини таъкидлайди:

1) семантик тасниф асосида қўлда разметкани автоматлаштирувчи семантик тахлил ёки “markup” дастури сифатида;

2) автоматик "markup" дастури сифатида.

Хар икки холатда хам хар хил турдаги омонимия масаласи чигал. Автоматик равишда хал қилиш деярли мумкин эмас (осон эмас). Шунинг учун яқин-яқингача самарали анализаторлар деярли йўқ эди. Олим фақат SemSin тизими ишлашини қайд этди [Захаров, 2020].

Манбалардаги семантик-синтактик парсерларни кузатар эканмиз, улар орасида семантик-синтактик (SemSin) парсер эътиборимизни тортди. Ушбу парсер тўрт блокдан иборат [Боярский, Каневский, 2012: 869-876]:

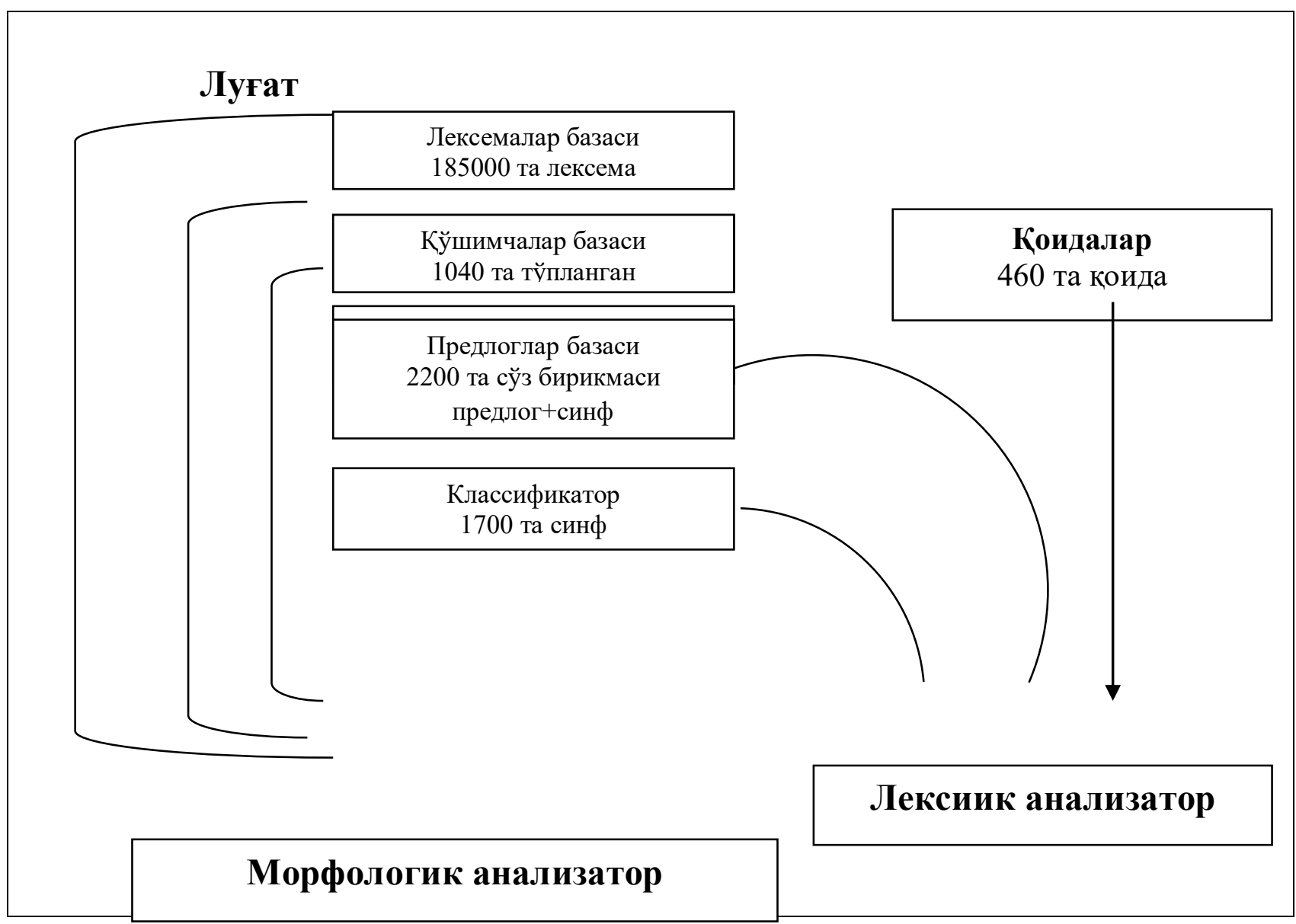




\section{1-расм. Парсернинг ишлаш схемаси}

Кўриниб турибдики, семантик-синтактик (SemSin) парсер луғат, морфологик анализатор, қоидалар ва лексик анализатор қисмларидан иборат. Парсернинг кириш қисми рус тилидаги параграфларга бўлинган матнлар билан таъминланади. Кейинги абзацда ажратилган токенлар (сўзлар, иборалар, тиниш белгилари, рақамлар ва бошқалар) морфологик тахлил қилинади. Сўнгра токенлар занжири ишлаб чиқариш қоидалари тизимидан фойдаланиб, лексик анализатор ишга тушади, унинг мақсади токенларнинг кетма-кетлигини шажара дарахтига айлантиришдир.

Англашиладики, семантик анализатор яратиш анча мураккаб вазифа. Бунинг учун биз даставвал семантик анализатор учун лингвистик таъминот масаласини хал қилишимиз зарур. Семантик анализатор - бу “тахлилнинг юраги": у дастурлаш тили билан боғлиқ барча қоидаларни билади. Семантик анализатор тилда мавжуд бўлган омоним, полифункционал ва кўп маъноли сўзларнинг маъносини фарқлашга хизмат қиладиган восита.

Юқоридаги кузатишларимиз асосида хулоса қилиш мумкинки, ўзбек тили семантик анализаторининг вазифаларига куйидагилар киради:

1. Сўзнинг лексик маъноларини аниқлаш.

2. Омонимларни фарқлаш.

3. Полифункционал сўзларни ажратиш.

4. Кўп маъноли сўзларнинг маъно қирраларини белгилаш.

Ўзбек Миллий корпусини яратишда лексик-семантик белгининг ноаниқлиги (омонимлиги)ни хал қилишда ишлатиладиган семантик фильтрлар тизимини ишлаб чиқиш бўйича тажрибалар олиб бориш долзарб вазифалардан. Бундай фильтрни яратиш учун ихтисослашган лексикографик манбалардан қай даражада фойдаланиш мумкинлигини текшириш мухим. Семантик анализатор учун лингвистик таъминот масаласи ечими ўзбек тили корпусларининг назарий асосларини ишлаб чиқиш, компьютер лингвистикаси йўналишида тадқиқотлар яратишда илмий-назарий манба сифатида хизмат қилади.

\section{Фойдаланилган адабиётлар:}

1. Сулейманов Д.Ш., Гатиатуллин А.Р. Структурно-функциональная компьютерная модель татарских морфем. - Казань: Фэн, 2003. - 220 с.

2. Семантический анализатор русскоязычного текста для вопросно- 
ответной системы // ДИССЕРТАЦИЯ на соискание ученой степени кандидата технических наук. - Петрозаводск, 2017. - 128 с.

3. PROMT Syntactic and Semantic Analyzer [Электрон pecypc]: http://www.promt.ru/company/technology/ analyzer/

4. Захаров В.П. Zоот дастури орқали ўтган маърузаси // 2020. 17. 12.

(Zaxarov V.P. Zoom dasturi orqali o'tgan ma'ruzasi // 2020. 17. 12.)

5. Боярский К.К., Каневский Е.А. Семантико-синтаксический парсер SemSin // Компьютерная лингвистика и интеллектуальные технологии. 2012. - C. 869-876. 